\title{
The Use Of Numbered Heads Together (Nht) Method To Improve Student's Writing Recount Text At First Grade Students Of MA Darul Aminin NW Aikmual In Academic Year 2014/2015
}

\author{
Suparlan \\ Suparlan@ nusantaraglobal.ac.id \\ Institut Pendidikan Nusantara Global, Jalan Raya Praya-Mantang Km-07 Aik Mual, Lombok \\ Tengah-NTB, 83511
}

\begin{abstract}
This study is purpose to find out the use of numbered heads together (NHT) method to improve student's writing recount text at first grade student of MA Darul Aminin NW Aikmal in academic year 2014/2015. There were 35 students of MA Darul Aminin NW Aikmual as the subject of the study. The type of this study was classroom action research. This action study was done in two cycles. Each cycle consist of four steps; Planning, Acting, Observing, and Reflecting. The data gathering used observation table check list and field note to obtain information about teacher, the student's activities and performance during the implementation of NHT method and quantitative data was gained from student's result writing test. The data analyzed use qualitative and quantitative approach. Based on the data analyzed was gotten that first, the students' ability in writing recount texts could be improved by using NHT method. Before the study was done, the mean score of students from 50.14 to 75.31 with percentage (25.71\%) to $(78.12 \%)$ is higher than criteria minimum (KKM). The students got score up than 70 there were 25 students with percentage $78.12 \%$. Second, the students' activeness increased from cycle 1 to cycle 2. Finally, it can be taken conclusion that there was the significant effect of Number heads Together (NHT) method to increase the students' writing ability in recount text at first grade student of MA Darul Aminin NW in academic year 2014/2015.
\end{abstract}

Keywords: Numbered heads together (NHT), Writing and Recount Text.

\section{INTRODUCTION}

\subsection{Background of the Study}

English is one of the language which very popular in the world, in this century every people learn it seriously, so that people must mastering all of the skill in English they are speaking, listening, reading, and writing. The researcher found the problem especially in writing skill when had observed in teaching training practice (PPL) on Augustus $23^{\text {th }}$ until November $23^{\text {th }}$ at MA Darul Aminin NW Aikmual. The writer was observed directly when English teacher teach their students and given them homework to write down their assignment of writing recount text. The result of the student hand writing did not really visible because they all only copy paste in other books and internet, they are not to practice their writing's ability. Therefore, the students cannot practice to write and think in creatively using their own words.
According Depdikbud (1982: 21), Writing means expressing feeling and idea in composition or in a letter which describing a language and is understood by everyone. It can also be said that writing is the effort to express oral language into written language by using sign (Suni: 1990; 8), therefore the students take study and practice more to develop this skill.

Freeman (1997: 89) explained that in writing, there are four aspects to be considered such as vocabulary, writing process, grammatical aspect, and the aspect of how to start writing. Therefore, all of the aspect must be mastering by the students.

By using Numbered Heads Together method, in teaching writing recount text, the Students are expected to be able to learn from their experiences and apply them to their lives. It helps with their creative thinking skills by showing that there are many ways to solve the problems. 


\subsection{Statement of the Problem}

Based on the background of the stated study above, The Problem has to be answered through this study is: how the use of numbered heads together(NHT) can improve student's writing recount text at the first grade students of MA Darul Amin NW Aikmual in academic year 2014/2015?

\subsection{Purpose of the Study}

Numbered heads together (NHT) can improve to find out: Whether the use of numbered heads student's writing recount text at the first grade students of MA DarulAminin NW Aikmual in academic year 2014/2015.

\subsection{Scope of the Study}

This study focused on the use of numbered heads together(NHT) to make the students work together in their groups so that they can improve their writing recount text especially to write their experiences in the past using their own words at the first grade students of MA Darul Aminin NW Akmual in academic year 2014/2015.

\subsection{Significance of the Study}

The study hopefully would give contribution both practically and theoretically.

\subsubsection{Practical}

This study would have students in writing recount text which content the events and experiences in the past by implementation of numbered heads together method.

\subsubsection{Theoretical}

The result of the study is as the parameter to know the level of student's ability in writing recount text especially at the first grade student of MA Darul Aminin NW Aikmual in academic year 2014/2015.

\subsection{Definition of the Key Term}

To avoid misunderstanding about the topic the following are the definitions of the key terms.

\subsubsection{Writing}

Writing means writing letter and number by using pencil or pen, and paper. According Depdikbud (1982: 21), Writing means expressing feeling and idea in composition or in a letter which describing a language and is understood by everyone. It can also be said that writing is the effort to express oral language into written language by using sign (Suni: 1990; 8).

\subsubsection{Recount Texts}

Recount Texts is the texts to retell past events for the purpose of informing or entertaining (Wadirman, 2008).

\subsubsection{Numbered heads together (NHT)}

Numbered Heads Together is an excellent structure for combining learning partnership into groups or team of four or more. According to Kagan (1994) Numbered Heads Together is a learning method when each student is given a number they make a group of work and then the teacher will call the number of students randomly.

\section{RESEARCH METHODS}

\subsection{Research Design}

This research was conducted by a classroom action research. Action research is the way groups of people can organize the conditions under which they can learn from their own experiences and make their experiences accessible to others.

Kemmis and McTaggart (2000: 595) describe it as participatory research that involves a spiral of self-reflective cycles of four stages, namely the cycle of plan, action, observation, and reflection. Action research was often conducted to discover a plan for innovation of interaction and collaborative.

\subsection{Population and Sample \\ 2.2.1 Population}

The writer selected the first grade of the student of MA Darul Aminin NW Aikmual which consists of 35 students, 22 males and 13 females.

\subsubsection{Sample}

Sample is smaller number of observations taken from the total number making up population. The sampling technique that was used in this study was cluster random sampling technique to determine this research. The writer takes 35 students as the sample of this study. 


\subsubsection{Method of Collecting Data}

Some of procedures were uses in class room action research they were; preliminary of study, planning, implementing, observing and reflecting.

\subsubsection{Preliminary of the study}

In preliminary of the study, the writer took part the English teacher to see the process in teaching learning by observe directly toward English teacher while teaching learning process to find out the problems appear, and it was found when English teacher teach their students and he given them the homework to write down their assignment of writing recount text. The result of the student hand writing did not really visible because they all only copy paste in other books and internet, they are not to practice their writing ability at that moment. Therefore, the students cannot practice to write and think in creatively using their own words.

\subsubsection{Planning}

In planning the writer prepares some steps. The steps for using numbered heads together that was applied by the writer in the classroom are:

2.2.3.2.1 Prepare a lesson plan.

2.2.3.2.2 Prepare observation table check list and field note it would uses to see the process of teaching learning and the result of the test concerning to the method being used.

2.2.3.2.3 Conducted the implementation of classroom action research. The steps of learning activity were written in the lesson plan.

2.2.3.2.4 Taken observation table check list and field note by concerning what were happened in the classroom during the process of teaching learning.

2.2.3.2.5 Evaluated and analyzed the whole data of observation.

2.2.3.2.6 Formulated the problems of the previous cycle.

2.2.3.2.7 Planned the next cycle.

\subsubsection{Implementing}

In implementing the planning there are some phases in teaching writing of recount text by using NHT are:

2.2.3.3.1 Pre-activity

2.2.3.3.2 Whilst activity

2.2.3.3.3 Post-activity

\subsubsection{Observing}

During the lesson, the teacher was observing the researcher teaching by applying numbered heads together method in writing recount text. It was done through the instrument used they were observation table check list and field notes in order to observe students' participation in the learning process.

2.2.3.4.1 The observer was observed directly toward English Teaching and learning process by filling the observation table check list for the students and for the teacher applying the method at first grade students of MA Darul Aminin NW in academic year 2014/2015.

2.2.3.4.2 Field notes are to uses to record detailed information about the implementation of the study. In addition it is uses to know the good point from the students, teacher's side and things to consider for the next meeting.

\subsection{Test}

The classroom action research was conducted into two cycles. There was also test in each cycle. The kind of test was the student hand writing about recount text based on their experiences. Test is some questions or exercises and to measure skill, knowledge, intelligent and attitude of someone or group of people (Burhan Bungin, 1992: 179).

\subsubsection{Reflecting}

This activity is evaluating about the change of students' success in learning situation and teacher. In this stage, the data gained from the test and the result of observation which was interpreted and analyzed whether the action activity results in the progress. The analysis is to know the weakness on the cycle 1 . If the result in cycle 1 achieved the goal, the research is accepted and stopped and if it does not achieved the goal the research will be continue to the cycle 2 , if the cycle 2 achieved the goal, the research is finish, and if it still does not achieved the goal the research will continuing to the next cycle.

The criteria of success if the requisition achieved as follow:

2.2.3.5.1 Minimum $75 \%$ the total of students active in learning process gained form observation table check list and field note.

2.2.3.5.2 Minimum 75\% the student's test result is higher than the criteria minimum (KKM) of English subject that is 70 . 


\section{RESEARCH FINDING}

\subsection{Research Finding}

Based on cycle 1, which have pointed out that the implementation of numbered heads together (NHT) method in writing recount text was still not completed yet, it was found that the students still lack about grammar in past form so, in this cycle the research was conducted on Monday may $12^{\text {th }}$ until Tuesday may $13^{\text {th }} 2014$. The writer continue chose the first grade student of MA Darul Aminin NW Aikmual and The class chosen was $\mathrm{X}$ consisted of 32 students because the three students were absent and divided into 8 groups, every groups consisted of 4 students. The writer and the English teacher as observer had to revise the lesson plan, optimizing time, and gave the more examples about recount text and at this time the teacher more intense to the students' ability in grammar and gave them more explanation about grammar especially in the past form.

\subsubsection{Data obtained from test}

As the cycle 1 there was a test in the end of the cycle, so in cycle 2 also has test. It was done to gain the data about the students' ability in writing recount text after the teaching and learning process.

\subsubsection{Data obtained from teaching learning process}

The data obtained in first cycle did not successful yet therefore, the writer continued in this cycle. In this cycle the study also conducted for two meeting same like first cycle, first meeting applied by the researcher came to the $\mathrm{X}$ class and greeted the students, their respond was very good enthusiasm, And the writer checked the student absents, but there were three students did not attended the class. There were 32 students and divided them randomly into eight groups that every groups consisted of four members and have them a number from one to four.

\subsection{References}

[6], According to Kagan (1994) Numbered Heads Together is a learning method when each student is given a number they make a group of work and then the teacher will call the number of students randomly.

\section{CONCLUSION}

Based on the statement of the problem on chapter I about how the use of numbered heads together can improve student's writing recount text? It through some steps they were:

First, the students' ability in writing recount texts could be improved by using NHT method. The mean score of students from 50.14 to 75.31 with percentage $(25.71 \%)$ to $(78.12 \%)$, the students got score up than 70 there were 25 students with percentage $78.12 \%$ is higher than criteria minimum (KKM).

Second, the students' activeness increased from cycle 1 to cycle 2 . Most of the students very active in teaching and learning Process that showed from observation table check list and field note, the result showed that the students gave their good attitudes and responses during teaching and learning process by applying the application of NHT (Numbered Heads Together) method and also could helps them in increasing their writing ability especially in writing recount text and also the students' motivation in learning English was increased.

In conclusion, the writer concluded that numbered heads together (NHT) can improve the students' ability in writing recount text at the first grade students of MA Darul Aminin NW Aikmual in academic year 201/2015.

\section{ACKNOWLEDGEMENT}

Dear all of my supporters such as my beloved wife Sulmiatun and all of my children, my close friend Jumadil, M.Pd., my parents, all of my friends, the best supporter Mr. Per and his whife and so on. I would like to thank all of you who supported me in writing this journal.

\section{REFFERENCES}

Ahmad, Sugeng and effendi. Developing English Competencies: for senior high school grade $X$, Pusat Perbukuan: Departemen Pendidikan Nasional.

Diane, Techniques and Principles in Language Teaching: Oxford university press.

Dorothy, Rumisek. Academic Writing: from paragraph to essay, Mac Millan.

Hidayatul Muawanah. 2012. Developing students' ability in writing recount texts by postcard; a case study at the first year 
students of man 2 mataram in academicyear 2011/2012. IKIP MATARAM

Joko, Virga and Irjayanti. Interlanguage: English for Senior High School Students $\mathrm{X}$, Pusat perbukuan: Departemen Pendidikan Nasional.

Kagan, Spencer. Cooperative Learning. San Clemente, CA: Kagan Publishing, 2009.

www.KaganOnline.com

Michael Gaffney. Participatory Action Research: An Overview. Deputy Director, Children's Issues Centre, Otago University, Dunedin: KAIRARANGA, 2008.

Riduwan, Metode dan Teknik Menyusun Tesis. Jakarta: Alfa Beta

Wendy Jolliffe. Cooperative Learning in the Class Room, P.C.P: Poul Chapman Publishing, 2007.

http://english.fkip.uns.ac.id (Accessed on January, 5th 2014)

http://1001skripsibahasainggris.blogspot.com/impr ove-students-reading-comprehension.html (Accessed on January, 5th 2014)

http://agunklik.blogspot.com/contoh-proposal-ptkbahasa-inggris.html

(Accessed on January, 5th 2014)

http://www.englishindo.com/recount-textpenjelasan-contoh.html

(Accessed on February, 12th 2014)

http://bukuisbn.blogspot.com/improving-studentswriting-ability-on.html (Accessed on February, 12 $2^{\text {th }} 2014$ ) 